Article

\title{
Label-Free Colorimetric Detection of Urine Glucose Based on Color Fading Using Smartphone Ambient- Light Sensor
}

\author{
Tian-Tian Wang ${ }^{1}$, Kun Guo ${ }^{1}$, Xue-Mei Hu ${ }^{2}$, Jian Liang ${ }^{3}$, Xing-De Li ${ }^{3}$, Zhi-Feng Zhang 1,* \\ and Jing $\mathrm{Xie}^{2, *}$ \\ 1 School of Pharmacy, Southwest Minzu University, Chengdu 610041, China; \\ 18268252522@163.com (T.-T.W.); guokunluohe@163.com (K.G.) \\ 2 School of Pharmacy, Chengdu Medical College, Chengdu 610500, China; xuemei.hu@163.com \\ 3 Chengdu Institute of Biology, Chinese Academy of Sciences, Chengdu 610041, China; \\ liangjian@cib.ac.cn (J.L.); li_xingde1975@163.com (X.-D.L.) \\ * Correspondence: zfzhang25@163.com (Z.-F.Z.); xiejing@cmc.edu.cn (J.X.); Tel.: +86-28-8552-2322 (Z.-F.Z.); \\ +86-28-6273-9561 (J.X.)
}

Received: 12 December 2019; Accepted: 20 January 2020; Published: 27 January 2020

\begin{abstract}
In this work, a label-free colorimetric assay was developed for the determination of urine glucose using smartphone ambient-light sensor (ALS). Using horseradish peroxidase-hydrogen peroxide $-3,3^{\prime}, 5,5^{\prime}$-tetramethylbenzidine $\left(\mathrm{HRP}-\mathrm{H}_{2} \mathrm{O}_{2}-\mathrm{TMB}\right)$ colored system, quantitative $\mathrm{H}_{2} \mathrm{O}_{2}$ was added to samples to-be-determined for deepest color. The presence of glucose oxidase in urine led to the formation of $\mathrm{H}_{2} \mathrm{O}_{2}$ and the reduction of $\mathrm{TMB}_{\text {red. }}$ As a result of this, the color of the urine faded and the solution changed from deep blue to light blue. We measured the illuminance of the transmitted light by a smartphone ambient light sensor, and thereby color changes were used to calculate the content of urine glucose. After method validation, this colorimetric assay was practically applied for the determination of urine samples from diabetic patients. Good linearity was obtained in the range of $0.039-10.000 \mathrm{mg} / \mathrm{mL}\left(\mathrm{R}^{2}=0.998\right)$, and a limit of detection was 0.005 $\mathrm{mg} / \mathrm{mL}$. Our method was had high accuracy, sensitivity, simplicity, rapidity, and visualization, providing a new sensor to be potentially applicable for point-of-care detection of urine glucose.
\end{abstract}

Keywords: urine glucose; smartphone; ambient light sensor; point-of-care detection

\section{Introduction}

Diabetes is a metabolic disease with high incidence rate in modern society, and there are globally millions of people suffering from this disease [1]. Although frequent blood-glucose monitoring can bring benefits to the health of diabetic patients [2], the disinfection process and stabbing pain during blood collection lead to very poor compliance. Besides blood glucose, the content of urine glucose is another important index for the clinical diagnosis and routine self-monitoring of the patients [3-5]. As urine glucose detection is non-invasive, patients' compliance is good, and more emphasis was placed on urine glucose determination.

Colorimetric analysis is a method to determine the content of a substance to-be-measured by the color of the solution that features good stability, low cost, and implementation simplicity, making it widely applied to clinical diagnosis and detection, including in glucose analysis [3,6-8]. However, current liquid colorimetry primarily requires lab-based infrastructure, and its utility greatly increases the use of point-of-use deployment. Though colorimetric analysis is strongly dependent on measurement, specific equipment such as ultraviolet-visible spectrometer, fluorescence spectrometer, Raman spectrometer, or an electrochemical workstation is required for data collection. 
Smartphones are convenient, could be widely applied, and offer good users' experience, making them effective instruments for on-site detection [9-11]. To date, most smartphone-based types of colorimetric analysis were reported using the phone's camera for directly capturing images from samples [11-14]. For example, $\mathrm{Xu}$ [13] and our group [15] took photos with a smartphone camera for the quantitative detection of blood and urinary glucose through RGB image analysis. However, there are certain issues that arise when a camera is used as a detector, such as smartphone brand, focusing location, distance between camera and samples, and exogenous light pollution [10]. Ambient-light sensors have been a new smartphone part in recent years that could automatically adjust the brightness of smartphone screen according to the intensity of environmental light $[16,17]$. The brightness of the current smartphone display immediately changes with the intensity of external light, because the lighting sensor embedded in the smartphone responds to the integrated light intensity of a wide range of wavelengths. There was a study that showed that the ambient-light-based biosensor could be utilized without any light-source restrictions [17]. Thus, colorimetric analysis based on ambient-light sensor could effectively avoid the problems on photographs, especially focusing and taking photograph of ambient light [17-19].

Horseradish peroxidase-hydrogen peroxide-3,3'5,5'-tetramethylbenzidine ( $\left.\mathrm{HRP}-\mathrm{H}_{2} \mathrm{O}_{2}-\mathrm{TMB}\right)$ is a coloring system that is commonly used in enzyme-linked immune-absorbent assay ELISA [20,21]. TMB is oxidized to blue in the presence of $\mathrm{HRP}$ and $\mathrm{H}_{2} \mathrm{O}_{2}$. We discovered the color-fading solution by excessive $\mathrm{H}_{2} \mathrm{O}_{2}$ color in the $\mathrm{HRP}-\mathrm{H}_{2} \mathrm{O}_{2}-\mathrm{TMB}$ system and developed colorimetric detection capable of quantitative analysis with a regular smartphone. There have yet been no reports of quantitative urine sugar testing by the smartphone ambient-light sensor. Therefore, according to standard laboratory operation, we published the principle and protocol of this method that was carried out with a microplate to meet general analytic requirements and applicable universality. The change of blue and $\mathrm{H}_{2} \mathrm{O}_{2}$ concentration was very obvious. For this, in this work we developed a label-free colorimetric analytical method based on an $\mathrm{HRP}-\mathrm{H}_{2} \mathrm{O}_{2}-\mathrm{TMB}$ coloring system using a smartphone ambient-light sensor as the data reader. First, quantitative $\mathrm{H}_{2} \mathrm{O}_{2}$ was added to urine to generate the deepest blue. Then, an amount of glucose oxidase (GOD) was added to generate $\mathrm{H}_{2} \mathrm{O}_{2}$ by glucose oxidation in the urine. The newly generated $\mathrm{H}_{2} \mathrm{O}_{2}$ could be faded, and the data could be read by the smartphone ambient-light sensor, realizing rapid determination of urine glucose. This proposed method has low cost, high accuracy, and offers material-free and equipment-free analysis, and a convenient, economical, and efficient detection method for diabetes.

\section{Materials and Methods}

\subsection{Reagents}

Glucose oxidase (GOD, $\geq 300 \mathrm{U} / \mathrm{g}$ ), 3,3'5,5'-tetramethylbenzidine (TMB) and horseradish peroxidase (HRP) were purchased from Shanghai Aladdin Bio-Chem Technology Co., Ltd. (Shanghai, China). Hydrogen peroxide $\left(\mathrm{H}_{2} \mathrm{O}_{2}\right)$, citric acid, potassium chloride $(\mathrm{KCl})$, sodium chloride $(\mathrm{NaCl})$, dipotassium hydrogen phosphate $\left(\mathrm{K}_{2} \mathrm{H}\left(\mathrm{PO}_{4}\right)_{3}\right)$, potassium dihydrogen phosphate $\left(\mathrm{KH}_{2}\left(\mathrm{PO}_{4}\right)_{3}\right)$ and $\mathrm{D}-(+)$-glucose were purchased from Sinopharm Chemical Reagent Co., Ltd. (Shanghai, China). The led lamp (LED) was purchased from the supermarket (Miniso, 2.4 W,10 × 19 $\times 35 \mathrm{~cm}$ ).

\subsection{Data Acquisition and Processing}

We placed a smartphone (MIX6X, Xiaomi Technology Co. Ltd., Beijing, China) flatly onto a table and under an LED, then placed the microplate on the smartphone screen for the ambient-light-sensor target of each microplate pole to-be-determined for data reading. The vertical distance between smartphone lamp-light center and ambient-light sensor was $20 \mathrm{~cm}$. Data processing was conducted with the LuxMeter application (Version 20180110). 


\subsection{Method Optimization}

\subsubsection{TMB and HRP Amount, and Reaction-Time Optimization}

A $4 \times 5$ hole microplate was selected as the experiment platform. Then, $30 \mu \mathrm{L}$ of TMB solution with concentrations of $1 \mathrm{mg} / \mathrm{mL}, 2 \mathrm{mg} / \mathrm{mL}, 3 \mathrm{mg} / \mathrm{mL}$, and $4 \mathrm{mg} / \mathrm{mL}$ was added in each horizontal line, and $30 \mu \mathrm{L}$ of HRP solutions with concentrations of $25 \mathrm{ng} / \mathrm{mL}, 50 \mathrm{ng} / \mathrm{mL}, 100 \mathrm{ng} / \mathrm{mL}, 200 \mathrm{ng} / \mathrm{mL}$, and $400 \mathrm{ng} / \mathrm{mL}$ was added in each vertical line, respectively. Then $10 \mu \mathrm{L}$ of $\mathrm{H}_{2} \mathrm{O}_{2}$ solution $(0.75 \%)$ and $130 \mu \mathrm{L}$ of the buffer were mixed together in each hole. After shaking slightly, we placed them until still and measured them at $1 \mathrm{~min}, 5 \mathrm{~min}, 10 \mathrm{~min}, 15 \mathrm{~min}$, and $20 \mathrm{~min}$ respectively.

\subsubsection{Additional $\mathrm{H}_{2} \mathrm{O}_{2}$ Quality Optimization}

First, $10 \mu \mathrm{L} \mathrm{H}_{2} \mathrm{O}_{2}$ solution, in concentrations 0, 0.005\%, 0.01\%, 0.015\%, 0.02\%, 0.026\%, 0.039\%, $0.078 \%, 0.156 \%, 0.313 \%, 0.625 \%, 1.25 \%, 2.5 \%$, and $5 \%$ was added into 14 microplate holes, respectively. Then $30 \mu \mathrm{L}$ of the TMB solution $(2 \mathrm{mg} / \mathrm{mL}), 10 \mu \mathrm{L}$ of the HRP solution $(100 \mathrm{ng} / \mathrm{mL})$, and $130 \mu \mathrm{L}$ of the buffer were added. After shaking slightly, we placed them until still and measured them at $10 \mathrm{~min}$.

\subsubsection{GOD Quality Optimization}

First, $50 \mu \mathrm{L}$ of the GOD solution, in concentrations of $1 \mathrm{mg} / \mathrm{mL}, 5 \mathrm{mg} / \mathrm{mL}, 10 \mathrm{mg} / \mathrm{mL}$, and 15 $\mathrm{mg} / \mathrm{mL}$ was added into the 4 microplate holes, respectively. Then, $30 \mu \mathrm{L}$ of TMB solution $(2 \mathrm{mg} / \mathrm{mL})$, $10 \mu \mathrm{L}$ of HRP solution $(100 \mathrm{ng} / \mathrm{mL}), 10 \mu \mathrm{L}$ of $\mathrm{H}_{2} \mathrm{O}_{2}$ solution $(0.75 \%)$, and $130 \mu \mathrm{L}$ of the buffer were added. After shaking slightly, we placed them until still and measured them at $10 \mathrm{~min}$.

\subsection{Urine Glucose Determination}

We mixed together $50 \mu \mathrm{L}$ of the urine sample, $30 \mu \mathrm{L}$ of the TMB solution $(2 \mathrm{mg} / \mathrm{mL}), 30 \mu \mathrm{L}$ of the HRP solution (100 ng/mL), $10 \mu \mathrm{L}$ of $\mathrm{H}_{2} \mathrm{O}_{2}$ solution $(0.078 \%), 50 \mu \mathrm{L}$ of GOD solution $(10 \mathrm{mg} / \mathrm{mL})$, and $130 \mu \mathrm{L}$ of the buffer, shook slightly, placed them until still, and measured at $10 \mathrm{~min}$.

\subsection{Validation Procedure}

Five solutions with respective concentrations of $0.039 \mathrm{mg} / \mathrm{mL}, 0.078 \mathrm{mg} / \mathrm{mL}, 0.313 \mathrm{mg} / \mathrm{mL}, 5.000$ $\mathrm{mg} / \mathrm{mL}$, and $10.000 \mathrm{mg} / \mathrm{mL}$ were prepared by glucose standard. After the Section 2.4 procedure, the calibration curve was calculated by linear regression between response value and glucose concentration, which is defined as follows: ordinates ( Ln Lux) was the intensity logarithm of transmitted light, and abscissa (Ln Glu) was the concentration logarithm. The limit of detection (LOD) was calculated by three-fold standard deviations (SD) of normal urine (blank sample). Precision was evaluated by intra- and inter-day precision, respectively. Intra- and inter-day precision was defined as the coefficient of variation $(\mathrm{CV})$ by nine replicates of three standard glucose solutions $(0.156$ $\mathrm{mg} / \mathrm{mL}, 1.250 \mathrm{mg} / \mathrm{mL}$, and $5.000 \mathrm{mg} / \mathrm{mL}$ ) within a day and in three days, respectively. Repeatability was evaluated through six independent determinations of a sample following Section 2.4 procedures. Recovery was evaluated by spiking $0.56 \mathrm{mg} / \mathrm{mL}, 0.70 \mathrm{mg} / \mathrm{mL}$, and $0.84 \mathrm{mg} / \mathrm{mL}$ of glucose solution (equivalent to $80 \%, 100 \%$, and $120 \%$ of glucose in sample) to a sample. After testing through the procedure of Section 2.4, recovery was calculated by the ratio of the detected added amounts.

\section{Results and Discussion}

\subsection{Analysis Principle}

The ambient-light sensor can automatically adjust screen brightness through sensing environmental light in which the smartphone is. Smartphone app LuxMeter is analytical software for light intensity that can measure the illuminance of the incident light. Thus, a smartphone can be used as a tool for quantitative measurement. Quantitative analysis became light-intensity analysis. The darker the solution was, the weaker the transmitted light intensity; and vice versa. In the present 
study, as there was correlation between glucose content in the sample solution and light intensity acquired by the smartphone, the transformation of solution color to light intensity could be the basis for quantitative calculation. Through analysis of 16 glucose solutions with different concentrations $(0.000 \mathrm{mg} / \mathrm{mL}, 0.002 \mathrm{mg} / \mathrm{mL}, 0.039 \mathrm{mg} / \mathrm{mL}, 0.078 \mathrm{mg} / \mathrm{mL}, 0.156 \mathrm{mg} / \mathrm{mL}, 0.313 \mathrm{mg} / \mathrm{mL}, 0.625 \mathrm{mg} / \mathrm{mL}$, $1.250 \mathrm{mg} / \mathrm{mL}, 1.880 \mathrm{mg} / \mathrm{mL}, 2.500 \mathrm{mg} / \mathrm{mL}, 3.750 \mathrm{mg} / \mathrm{mL}, 5.000 \mathrm{mg} / \mathrm{mL}, 10.000 \mathrm{mg} / \mathrm{mL}, 15.00 \mathrm{mg} / \mathrm{mL}$, $20.000 \mathrm{mg} / \mathrm{mL}$, and $30.000 \mathrm{mg} / \mathrm{mL}$ ), it was revealed that glucose content was inversely correlated with solution color, which is shown in Figure 1A. By further analyzing the glucose concentration within a certain range and its corresponding intensity of transmission light, the functional relations between them could apply to achieve quantitative analysis. The relationship graphs between the logarithm of transmitted light intensity (Ln Lux) and logarithm of glucose concentration (Ln Glu) are shown in Figure 1. When glucose concentration was in the range of $0-30 \mathrm{mg} / \mathrm{mL}$, LnLux is positively correlated with LnGlu, but there was no linear relationship between LnLux and LnGlu (Figure 1B), which can only be used for qualitative analysis. While when glucose concentration was in the range of 0.039-10 $\mathrm{mg} / \mathrm{mL}$, LnLux and LnGlu have good linearity (Figure 1C) and can be used for quantitative analysis.

$\mathbf{A}$
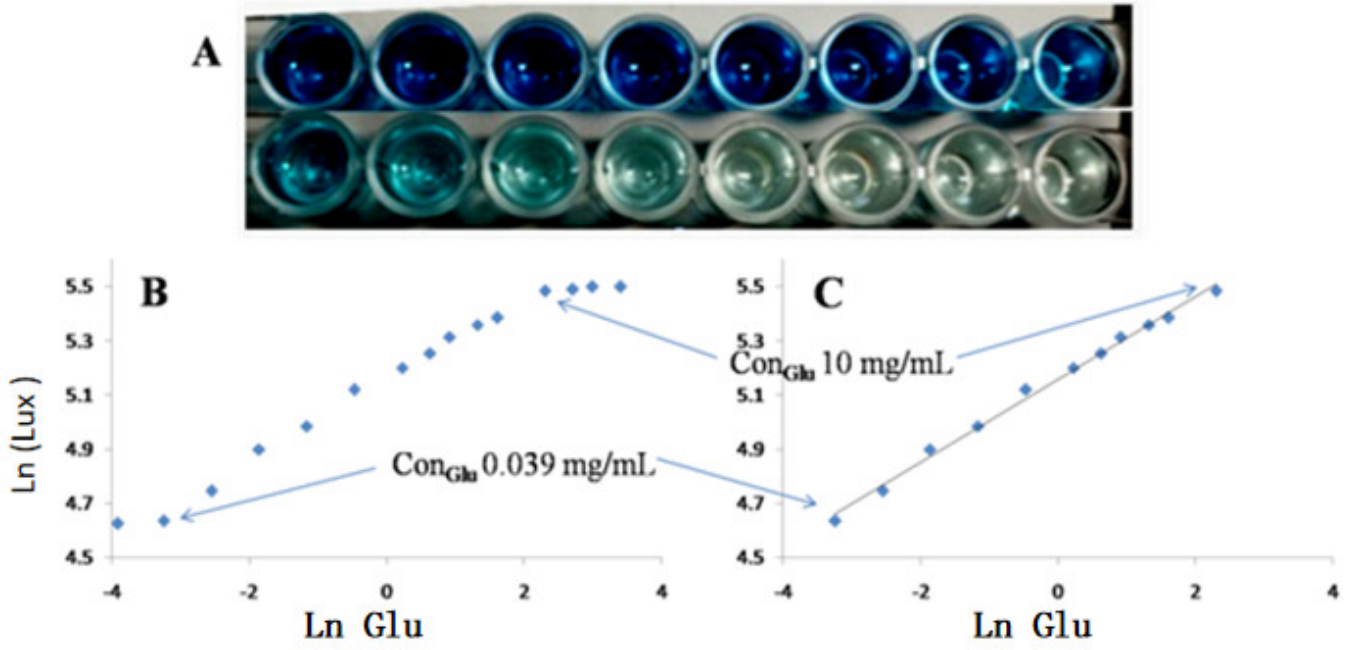

Figure 1. Different colors (A) of glucose solutions with different concentrations; linear relationship between LnLux and LnGlu (B,C); From figure C, we can see that LnLux and LnGlu have a good linearity and can be used for quantitative analysis in the range of $0.039-10 \mathrm{mg} / \mathrm{mL}$.

Hydrogen peroxide $\left(\mathrm{H}_{2} \mathrm{O}_{2}\right)$ was generated by the oxidation of glucose in the urine sample under glucose oxidase (GOD) catalysis. Then, the white 3,3',5,5'-tetramethylbenzidine (TMBred) was oxidized by horseradish peroxidase (HRP) to its blue oxidized product ( $\left.\mathrm{TMB}_{\mathrm{ox}}\right)$ with the participation of $\mathrm{H}_{2} \mathrm{O}_{2}$ [22]. Since $\mathrm{H}_{2} \mathrm{O}_{2}$ was also the enzyme inhibitor of HRP [23], it could be observed that, with the concentration increase of $\mathrm{H}_{2} \mathrm{O}_{2}$, the blue color of the solution first deepened, then lightened, until it was finally colorless. The color-fading stage was a continuous and gradual process with a long concentration range of $\mathrm{H}_{2} \mathrm{O}_{2}$. With the help of this phenomenon, not only could the qualitative analysis be visualized, but quantitative analysis can also be carried out by using the smartphone. In the present study, quantitative $\mathrm{H}_{2} \mathrm{O}_{2}$ was first added to urine to generate the deepest blue. Then, an amount of GOD was added to generate $\mathrm{H}_{2} \mathrm{O}_{2}$ by glucose oxidation in the urine. The newly generated $\mathrm{H}_{2} \mathrm{O}_{2}$ could shallow the solution color, and we finally used the smartphone ambient-light sensor for data reading, thus realizing the rapid determination of urine glucose. The above procedure is shown in Figure 2. 


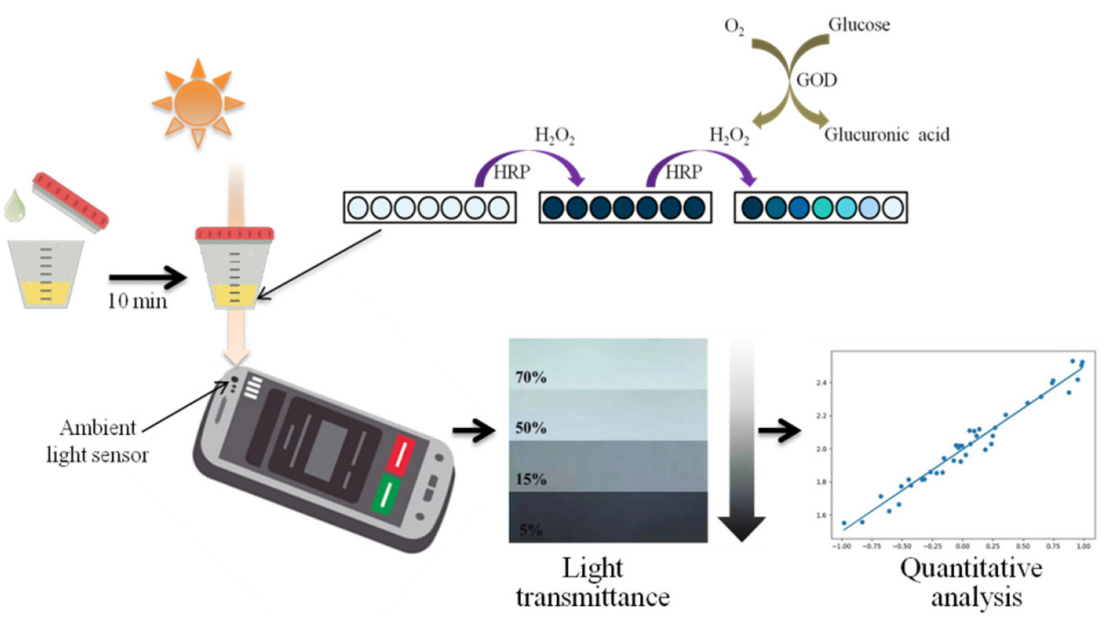

Figure 2. Illustration of the proposed analytical procedure.

\subsection{Optimized-Experiment Results}

\subsubsection{TMB and HRP Amount, and Reaction Time}

The white $\mathrm{TMB}_{\text {red }}$ was oxidized by $\mathrm{HRP}$ to its blue oxidized product (TMBox) with $\mathrm{H}_{2} \mathrm{O}_{2}$ participation. Results showed that the amount of TMB had little effect on coloration. However, HRP content was a key factor that had a negative correlation with coloration. After optimization, HRP and TMB concentrations were set to $100 \mathrm{ng} / \mathrm{mL}$ and $2 \mathrm{mg} / \mathrm{mL}$, respectively. As for the choice of best reaction time, the solution color was very unstable in $5 \mathrm{~min}$, solution color was almost stable in 10 min. Therefore, the preferred test point was set at $10 \mathrm{~min}$.

\subsubsection{Optimized Results of Additional $\mathrm{H}_{2} \mathrm{O}_{2}$ Amount}

The key parameter of this work was the $\mathrm{H}_{2} \mathrm{O}_{2}$ amount. By investigating 14 batches of $\mathrm{H}_{2} \mathrm{O}_{2}$ solutions with different concentration level (0-5\%), as shown in Figure 3 (top), with the concentration increase of $\mathrm{H}_{2} \mathrm{O}_{2}$, the blue of the solution first deepened, then lightened, until it was finally colorless. The color-fading stage was a continuous and gradual process with a long concentration range of $\mathrm{H}_{2} \mathrm{O}_{2}$. In addition, by plotting the curve between the logarithm of transmitted light intensity (Ln Lux) and the logarithm of $\mathrm{H}_{2} \mathrm{O}_{2}$ concentration, as shown in Figure 3 (right), the inflection point of concentration was $0.078 \%$, which was in accordance with the visual observation shown in Figure 3 (left). Therefore, the concentration of added $\mathrm{H}_{2} \mathrm{O}_{2}$ was set to $0.078 \%$.

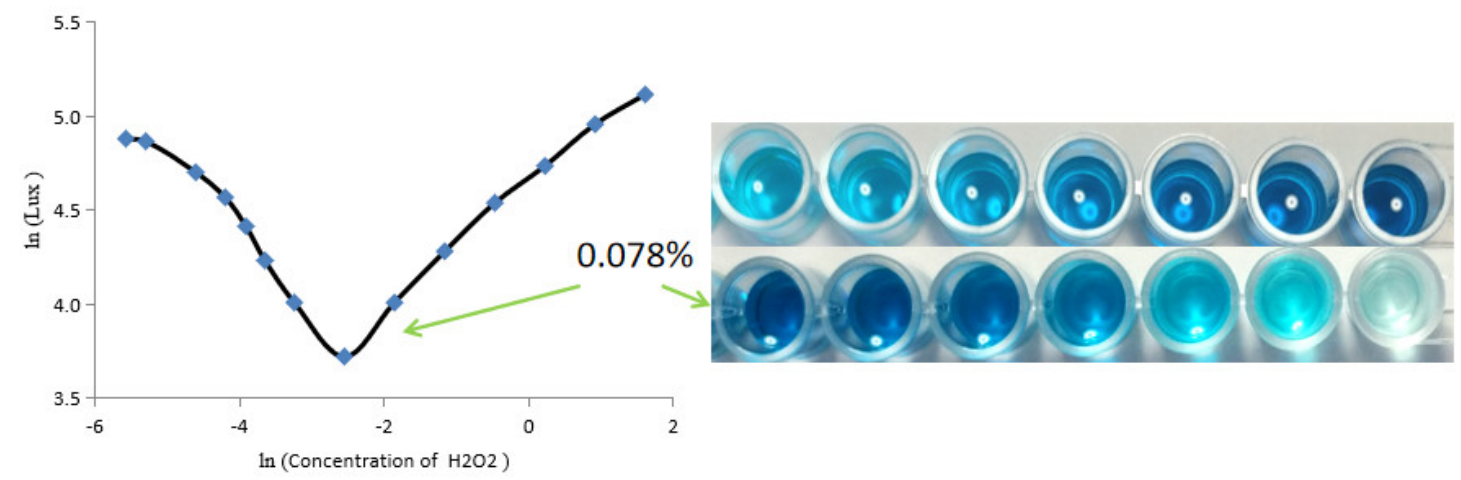

Figure 3. Qualitative observation (right) and quantitative curve (left) of the relationship between the $\mathrm{H}_{2} \mathrm{O}_{2}$ concentration and light intensity. 


\subsection{Method Validation}

Here, we described that when glucose concentration is in the range of $0.039-10 \mathrm{mg} / \mathrm{mL}$, the logarithm of glucose concentration (lnGlu) and the logarithm of light intensity (lnLux) had good linearity (Figure 1C) and could be used for quantitative analysis. The linear-calibration curve was established as $\mathrm{y}=0.0804 \mathrm{x}+4.9127(0.039-10 \mathrm{mg} / \mathrm{mL})$ with good correlation $\left(\mathrm{R}^{2}=0.998\right)$. LOD was determined as $0.005 \mathrm{mg} / \mathrm{mL}$. Intra- and inter-day precision CVs were $1.63 \% \sim 3.12 \%$ and $1.57 \% \sim 3.62 \%$, respectively, indicating that the method had good precision. Repeatability was evaluated with six replicates as previously described, which was $0.70 \pm 0.02 \mathrm{mg} / \mathrm{mL}$ with a CV of $4.7 \%$. Recovery was evaluated by spiking three levels of glucose $(0.56 \mathrm{mg} / \mathrm{mL}, 0.70 \mathrm{mg} / \mathrm{mL}$, and $0.84 \mathrm{mg} / \mathrm{mL})$ into the urine sample, respectively. By calculating the ratio of the detected added amounts, mean recoveries were $93.33 \% \pm 2.97 \%, 93.81 \% \pm 2.18 \%$, and $95.28 \% \pm 6.23 \%$, indicating good recovery. By the above method validation, it was revealed that the established analytical method met the requirements of quantitative analysis and could be used for glucose determination in urine samples. The comparison between the proposed method and an existing method for glucose determination, as shown in Table 1.

Table 1. Comparison of the analytical methods for glucose detection.

\begin{tabular}{|c|c|c|c|c|c|}
\hline Analyte & Probe & Detection Method & $\begin{array}{c}\text { Linear Response } \\
\text { Range }\end{array}$ & LOD & Reference \\
\hline \multirow{8}{*}{ Glucose } & GRGO/AC a & $\begin{array}{l}\text { Cyclic voltammetry } \\
\text { method }\end{array}$ & $0.002-10 \mathrm{mM}$ & $2 \mu \mathrm{M}$ & [24] \\
\hline & $\begin{array}{c}\text { Ag@Au-Ir-Zne } \\
\text { MOFs b }\end{array}$ & $\begin{array}{c}\text { Phosphorescence } \\
\text { intensity }\end{array}$ & $0.05-30.0 \mathrm{mM}$ & $\begin{array}{c}0.038 \\
\mathrm{mM}\end{array}$ & [7] \\
\hline & Ag3 & $\begin{array}{l}\text { Phosphorescence } \\
\text { intensity }\end{array}$ & $1.0-35 \mathrm{mM}$ & $\begin{array}{l}0.09 \\
\mathrm{mM}\end{array}$ & [25] \\
\hline & NB-CNPs c & $\begin{array}{c}\text { Fluorescence } \\
\text { quenching }\end{array}$ & $0-900 \mu \mathrm{M}$ & $1.8 \mu \mathrm{M}$ & [8] \\
\hline & $\mathrm{ZnFe}_{2} \mathrm{O}_{4} \mathrm{MNPS}^{\mathrm{d}}$ & Colorimetric detection & $1.25-18.75 \mu \mathrm{M}$ & $0.3 \mu \mathrm{M}$ & [6] \\
\hline & $\begin{array}{l}\mu \text { PADs with } \\
\text { chitosan }^{e}\end{array}$ & Colorimetric detection & $130-380 \mu \mathrm{M}$ & $27 \mu \mathrm{M}$ & [26] \\
\hline & GR-CNT-ZnO ${ }^{\mathrm{f}}$ & Electrochemistry & - & $4.5 \mu \mathrm{M}$ & [27] \\
\hline & - & Phone ALS detection $\mathrm{g}$ & $0.2-55.6 \mu \mathrm{M}$ & $\begin{array}{l}0.03 \\
\mu \mathrm{M}\end{array}$ & This work \\
\hline
\end{tabular}

GRGO/AC a Plain to point network reduced graphene oxide-activated carbon composites decorated with platinum nanoparticles; Ag@Au-Ir-Zne MOFs b $\mathrm{g} @ \mathrm{Au}$ nanoprism-metal-organic frameworks (MOFs); NB-CNPs ${ }^{c}$ boron co-doped carbon nanoparticles; $\mathrm{ZnFe}_{2} \mathrm{O}_{4} \mathrm{MNPs}^{\mathrm{d}} \mathrm{ZnFe}_{2} \mathrm{O}_{4}$ magnetic nanoparticles; $\mu$ PADs e microfluidic paper-based analytical devices; GR-CNT-ZnO ${ }^{\text {f }}$ graphene-carbon nanotubes-zinc oxide nanoparticles hybrid; ALS g ambient light sensor.

\subsection{Glucose Determination in Urine Samples}

The glucose content in urine samples of four diabetic patients was determined by the present method. Results were $0.14 \pm 0.02,0.70 \pm 0.03,0.25 \pm 0.02$, and $0.31 \pm 0.02 \mathrm{mg} / \mathrm{mL}$, respectively.

\section{Conclusions}

In this study, we developed a label-free colorimetric assay using a smartphone ambient-light sensor that could directly determine the urine glucose at the point-of-care. Glucose sensing for diabetes monitoring applied by smartphone was reported, but without ambient- light- sensor analysis. These tests can only be used in daily practice as a rough screening test. $\mathrm{H}_{2} \mathrm{O}_{2}$ is an inhibitor of $\mathrm{HRP}$, so in $\mathrm{HRP}-\mathrm{H}_{2} \mathrm{O}_{2}-\mathrm{TMB}$ system, excessive and quantitative $\mathrm{H}_{2} \mathrm{O}_{2}$ was added in advance, and the color of the solution changed gradually in different glucose levels. This can help realize the qualitative analysis for urine glucose level in diabetic patients via the smartphone ambient-light 
sensor. After methodological validation, our method had wide linear range, good repeatability, and high accuracy, making it simple and convenient for the routine monitoring of urine glucose.

Author Contributions: Conceptualization, Z.-F.Z.; data curation, K.G. and X.-D.L.; formal analysis, T.-T.W.; funding acquisition, T.-T.W.; investigation, X.-M.H.; project administration, Z.-F.Z. and J.X.; supervision, Z.-F.Z. and J.X.; validation, J.L.; writing - original draft, Z.-F.Z.; writing - review and editing, J.X. All authors have read and agreed to the published version of the manuscript.

Funding: This work was supported by The National Key Technology R \& D Program (NO. 2019YFC1712503), Innovative Research Program for Graduates of Southwest Minzu University (No. CX2019SZ177), and Health Commission of Sichuan Province, China (No. 18PJ549).

Conflicts of Interest: The authors declare no conflict of interest.

\section{References}

1. Cho, N.H.; Shaw, J.E.; Karuranga, S.; Huang, Y.; da Rocha Fernandes, J.D.; Ohlrogge, A.W.; Malanda, B. IDF Diabetes Atlas: Global estimates of diabetes prevalence for 2017 and projections for 2045. Diabetes Res. Clin. Pract. 2018, 138, 271-281.

2. Clarke, S.F.; Foster, J.R. A history of blood glucose meters and their role in self-monitoring of diabetes mellitus. Br. J. Biomed. Sci. 2012, 69, 83-93.

3. Karim, M.N.; Anderson, S.R.; Singh, S.; Ramanathan, R.; Bansal, V. Nanostructured silver fabric as a freestanding NanoZyme for colorimetric detection of glucose in urine. Biosens. Bioelectron. 2018, 110, 8-15.

4. Van Enter, B.J.; von Hauff, E. Challenges and perspectives in continuous glucose monitoring. Chem. Commun. 2018, 54, 5032-5045.

5. Wang, Q.-L.; Xie, J.; Liang, J.; Dong, G.-T.; Ding, L.-S.; Luo, P.; Qing, L.-S. Competitive Protein Binding Assay of Naproxen by Human Serum Albumin Functionalized Silicon Dioxide Nanoparticles. Molecules 2019, 24, 2593.

6. Su, L.; Feng, J.; Zhou, X.; Ren, C.; Li, H.; Chen, X. Colorimetric Detection of Urine Glucose Based $\mathrm{ZnFe}_{2} \mathrm{O}_{4}$ Magnetic Nanoparticles. Anal. Chem. 2012, 84, 5753-5758.

7. Huang, P.-H.; Hong, C.P.; Zhu, J.F.; Chen, T.-T.; Chan, C.-T.; Ko, Y.-C.; Lin, T.-L.; Pan, Z.-B.; Sun, N.-K.; Wang, Y.-C.; et al. Ag@Au nanoprism-metal organic framework-based paper for extending the glucose sensing range in human serum and urine. Dalton Trans. 2017, 46, 6985-6993.

8. Liang, M.; Ren, Y.; Zhang, H.; Ma, Y.; Niu, X.; Chen, X. One-step synthesis of nitrogen, boron co-doped fluorescent carbon nanoparticles for glucose detection. Luminescence 2017, 32, 1031-1038.

9. Vashist, S.K.; Luong, J.H.T. Commercially Available Smartphone-Based Personalized Mobile Healthcare Technologies. In Point-of-Care Technologies Enabling Next-Generation Healthcare Monitoring and Management; Springer International Publishing: Cham, Switzerland, 2019; 10, 81-115.

10. Kanchi, S.; Sabela, M.I.; Mdluli, P.S.; Inamuddin; Bisetty, K. Smartphone based bioanalytical and diagnosis applications: A review. Biosens. Bioelectron. 2018, 102, 136-149.

11. Wang, Q.-L.; Huang, W.-X.; Zhang, P.-J.; Chen, L.; Lio, C.-K.; Zhou, H.; Qing, L.-S.; Luo, P. Colorimetric determination of the early biomarker hypoxia-inducible factor-1 alpha (HIF-1 $\alpha$ ) in circulating exosomes by using a gold seed-coated with aptamer-functionalized Au@Au core-shell peroxidase mimic. Microchim. Acta 2020, 187, 61.

12. Nguyen, T.T.; Vandevoorde, K.; Wouters, N.; Kayacan, E.; De Baerdemaeker, J.G.; Saeys, W. Detection of red and bicoloured apples on tree with an RGB-D camera. Biosyst. Eng. 2016, 146, 33-44.

13. Wang, X.; Li, F.; Cai, Z.; Liu, K.; Li, J.; Zhang, B.; He, J. Sensitive colorimetric assay for uric acid and glucose detection based on multilayer-modified paper with smartphone as signal readout. Anal. Bioanal. Chem. 2018, 410, 2647-2655.

14. Yang, X.; Wang, Y.; Liu, W.; Zhang, Y.; Zheng, F.; Wang, S.; Zhang, D.; Wang, J. A portable system for onsite quantification of formaldehyde in air based on G-quadruplex halves coupled with A smartphone reader. Biosens. Bioelectron. 2016, 75, 48-54.

15. Wang, T.-T.; Lio, C.k.; Huang, H.; Wang, R.-Y.; Zhou, H.; Luo, P.; Qing, L.-S. A feasible image-based colorimetric assay using a smartphone RGB camera for point-of-care monitoring of diabetes. Talanta 2020, 206, 120211.

16. Dutta, S. Point of care sensing and biosensing using ambient light sensor of smartphone: Critical review. TrAC Trends Anal. Chem. 2019, 110, 393-400. 
17. Park, Y.M.; Han, Y.D.; Chun, H.J.; Yoon, H.C. Ambient light-based optical biosensing platform with smartphone-embedded illumination sensor. Biosens. Bioelectron. 2017, 93, 205-211.

18. Chen, Y.; Fu, Q.; Li, D.; Xie, J.; Ke, D.; Song, Q.; Tang, Y.; Wang, H. A smartphone colorimetric reader integrated with an ambient light sensor and a 3D printed attachment for on-site detection of zearalenone. Anal. Bioanal. Chem. 2017, 409, 6567-6574.

19. Fu, Q.; Wu, Z.; Li, X.; Yao, C.; Yu, S.; Xiao, W.; Tang, Y. Novel versatile smart phone based Microplate readers for on-site diagnoses. Biosens. Bioelectron. 2016, 81, 524-531.

20. Wang, Q.-L.; Li, J.; Li, X.-D.; Ding, L.-S.; Xie, J.; Qing, L.-S. A simple nano-SiOz-based ELISA method for residue detection of 2,4-dichlorophenoxyacetic acid in bean sprouts. Food Anal. Methods 2017, 10, 1500-1506.

21. Wang, Q.-L.; Li, J.; Li, X.-D.; Tao, W.-J.; Ding, L.-S.; Luo, P.; Qing, L.-S. An efficient direct competitive nanoELISA for residual BSA determination in vaccines. Anal. Bioanal. Chem. 2017, 409, 4607-4614.

22. Wang, Q.-L.; Xie, J.; Li, X.-D.; Ding, L.-S.; Liang, J.; Luo, P.; Qing, L.-S. Development of a nano-SiOz based enzyme-linked ligand binding assay for the determination of ibuprofen in human urine. Talanta 2017, 167, 617-622.

23. Arnao, M.B.; Acosta, M.; Rio, J.A.D.; Varón, R.; García-Cánovas, F. A kinetic study on the suicide inactivation of peroxidase by hydrogen peroxide. Biochim. Biophys. Acta 1990, 1041, 43-47.

24. Hossain, M.F.; Park, J.Y., Plain to point network reduced graphene oxide - activated carbon composites decorated with platinum nanoparticles for urine glucose detection. Sci. Rep. 2016, 6, 21009.

25. Pan, Z.B.; Wang, Y.C.; Chakkaradhari, G.; Zhu, J.F.; He, R.Y.; Liu, Y.C.; Hsu, C.H.; Koshevoy, I.O.; Chou, P.T.; Pan, S.W., A silver metal complex as a luminescent probe for enzymatic sensing of glucose in blood plasma and urine. Dalton Transactions 2018, 10, 1039.

26. Gabriel, E.F.M.; Garcia, P.T.; Cardoso, T.M.G.; Lopes, F.M.; Martins, F.T.; Coltro, W.K.T., Highly sensitive colorimetric detection of glucose and uric acid in biological fluids using chitosan-modified paper microfluidic devices. The Analyst 2016, 141, 4749.

27. Ciucu, A.; Anton, Chemically Modified Electrodes in Biosensing. J. Biosen. Bioelectron. 2014, 5, 1000154.

(C) 2020 by the authors. Licensee MDPI, Basel, Switzerland. This article is an open access article distributed under the terms and conditions of the Creative Commons Attribution (CC BY) license (http://creativecommons.org/licenses/by/4.0/). 